\title{
Occurrence and Enumeration of Multiple Bacterial Pathogens in Edible Snails from South East Nigeria
}

\author{
Arthur C. Okafor ${ }^{1, *}$, Frank C. Ogbo ${ }^{2}$ \\ ${ }^{1}$ Department of Microbiology, Edo University Iyamho, Nigeria \\ ${ }^{2}$ Department of Applied Microbiology and Brewing, Nnamdi Azikiwe University, Nigeria
}

Copyright $(2019$ by authors, all rights reserved. Authors agree that this article remains permanently open access under the terms of the Creative Commons Attribution License 4.0 International License

\begin{abstract}
Edible snails are usually obtained from the forest and in high demand among consumers. Data on the level of contamination of edible snails with bacterial pathogens are needed for making legislations that will improve food safety and protect public health. This study aimed to determine the occurrence and distribution of counts of selected bacterial pathogens in Achatina achatina from major markets within South East Nigeria. A total of 300 samples of $A$. achatina were examined for occurrence and counts of Citrobacter, Shigella, Escherichia coli, Staphylococcus, Aeromonas and Bacillus cereus using enrichment broth, differential and selective media. Snail samples from Ogbete market had the highest mean aerobic plate count $(9.32 \pm 0.308 \mathrm{Log} \mathrm{CFU} / \mathrm{g})$, while Abakaliki market samples had highest mean count of coliforms (7.63 $\pm 0.389 \mathrm{Log} \mathrm{CFU} / \mathrm{g}$ ). Among pathogens, highest counts were observed for Citrobacter and E. coli which ranged from 6.0 to $8.0 \mathrm{Log}$ CFU/g in $300(100 \%)$ and $180(60 \%)$ samples respectively. Significant differences were observed among the locations $(p<0.01)$. Our findings highlight the need for formulation and implementation of strategies for the reduction of bacterial pathogens in edible snails along the value chain.
\end{abstract}

Keywords Achatina achatina, Aeromonas, Bacillus cereus, Citrobacter, Escherichia coli, Staphylococcus

\section{Introduction}

Foodborne diseases cause significant burden of disability and mortality in most countries. Diarrhoeal diseases are the most common illnesses resulting from the consumption of contaminated foods, causing 550 million people to fall ill and 230,000 deaths annually (WHO, 2017). Currently, Nigeria's diarrhoea prevalence is $18.8 \%$ according to the joint report from the federal ministries of Agriculture, Environment and Health (FMAEH, 2017).

Food poisoning and diarrhoea caused by foods contaminated by Citrobacter have been reported (Doulgeraki et al., 2011). Currently, the incidence of shigellosis worldwide is highest among children less than five years of age (Taneja and Mewara, 2016). E. coli is one of the major foodborne pathogens of foods of animal origin with wide variability of virulence (Kobayashi et al., 2002; Johnson et al., 2005). Aeromonas have been associated with several food-borne outbreaks and are progressively being isolated from patients with traveler's diarrhoea (Von Graevenitz, 2007). The true burden of illnesses caused by $B$. cereus is unknown probably because they commonly occur as sporadic cases, rather than in major outbreaks (Logan et al., 2011).

All food groups contribute to the burden of foodborne diseases, and foods of animal origin cause the highest burden (Havelaar, 2016). Carriage and shedding of zoonotic pathogens contaminate the environment and eventually enters the food chain during processing and post processing procedures (Coker et al., 2000). However, most people are inadvertently exposed to microbial hazards from several other sources (Okafor et al., 2017; Amini et al., 2012), which can cause diseases that go unreported. The proportion of the national burden of disease linked to the environment in Nigeria is 29\% (WHO, 2009).

Snails are consumed by the people of both rural and urban communities (Efuntoye et al., 2011). The most common species in West Africa is Achatina achatina (Hodasi, 1984). Consumption level of snail meat among people of Bori (a southern city in Nigeria) is as high as 70\% (Nodu et al., 2003). The global snail market has recorded a turnover of 10 billion Euros per year with consumption of about 400,000 tons of snails, of which only 50,000 tons were produced in snail farms (Toader, 2012).

However, mild gastroenteritis has been reported to be common among people that consume snails regularly (Serrano et al., 2004). Bacterial pathogens have been detected from varieties of snails in previous studies (Adegoke et al., 2010; Omenewa et al., 2011, Adagbada et al., 2011; Ebenso et al., 2012; Nyoagbe et al., 2016). However, there is limited data on the comparative 
distribution of viable counts of multiple bacterial pathogens among snails displayed for sale in markets in more than two states in Nigeria. Such data is important for making legislations that will improve food safety.

The objective of this study was to determine the occurrence and distribution of the viable counts of Citrobacter, Shigella, E. coli, Staphylococcus, Aeromonas and Bacillus cereus in A. achatina from major markets in three states within South east geopolitical zone of Nigeria.

\section{Materials and Methods}

\subsection{Collection of Snail Samples}

A total of 300 samples of live edible snails (Achatina achatina) were randomly collected from markets in south east, Nigeria and analysed: comprising of hundred samples each from three states in south east geopolitical zone of Nigeria, namely Anambra, Ebonyi and Enugu. Central markets serving as the largest platforms for sale of live edible snails in these states were selected for this study. They were: Ogbete main market at Enugu State, Abakaliki meat market at Ebonyi State and Nkwo Igboukwu market at Anambra State. Samples were collected from July 2016December 2016 and April 2017-June 2017.

Edible Snails (A. achatina) were identified according to their shape, size, markings, colour, spire angle, sculpture and aperture form (Igbinosa et al., 2016; Raut and Barker, 2002). Edible snails displayed on the tables for sale were aseptically collected in plastic containers sterilized with 70\% alcohol and dried with commercially available sterile paper towel. Samples were quickly transported to the laboratory for analysis.

\subsection{Sample Preparation}

The shells of the snails were surface sterilized with $70 \%$ ethanol before being aseptically shucked with a sterile iron rod to extract the meat. The lab blender was sterilized with $70 \%$ ethanol. The sample $(50 \mathrm{~g})$ was homogenized in 450 $\mathrm{ml}$ of Ringers solution (Oxoid) using the lab blender for 2 mins at medium speed. The homogenate was used for serial dilution (1:10). Aliquot $(1 \mathrm{ml})$ of appropriate dilution factor was used for determination of bacterial counts

\subsection{Determination of Total Aerobic Plate Count}

Plate count agar (Oxoid) was prepared according to manufacturer's instructions and maintained at $45^{\circ} \mathrm{C}$. Aliquot $(1 \mathrm{ml})$ of appropriate dilution factor $\left(10^{-6}-10^{-8}\right)$ of the homogenate was pipetted into sterile petri dish and the molten agar media was poured into the petri dish. The plate was swirled to mix the homogenate with the agar media. It was done in triplicates for each sample. Plates were incubated aerobically at $37^{\circ} \mathrm{C}$ for 24 hours after which colonies were counted and recorded.

\subsection{Determination of Coliform Count}

MacConkey agar (Titan) was prepared according to manufacturer's instructions. Aliquot $(0.1 \mathrm{ml})$ of appropriate dilution factor was plated out on the agar medium. It was done in triplicates for each sample. Plates were incubated aerobically at $37^{\circ} \mathrm{C}$ for 24 hours after which pink colonies were counted and recorded.

\subsection{Determination of Viable Counts of Bacterial Pathogens}

All agar media namely: Salmonella-Shigella agar (Biotech), Eosin Methylene Blue agar (Oxoid), Mannitol Salt agar (Oxoid), Thiosulfate Citrate Bile salt Sucrose agar (Titan) and Brain Heart Infusion agar (Titan) were prepared according to manufacturer's instructions.

Aliquot $(0.1 \mathrm{ml})$ of appropriate dilution factors was directly plated out on appropriate agar media, except Brain Heart Infusion agar, specific for each pathogen and incubated aerobically at $37^{\circ} \mathrm{C}$ for 24 hours. It was done in triplicates for each sample. Typical colonies were counted and recorded after 24 hours. However, appropriate dilution factors were heated in a water bath at $80^{\circ} \mathrm{C}$ for 10 mins before being plated on Brain Heart Infusion agar. It was done in triplicates for each sample. Plates were incubated aerobically at $37^{0} \mathrm{C}$ for 24 hours after which typical colonies of Bacillus cereus were counted and recorded.

\subsection{Isolation and Identification of Selected Bacterial Pathogens}

The procedure for identification of the six genera of bacterial pathogens was based on the United Kingdom Standards for Microbiology Investigations as published by Public Health England (2014 and 2015) and is discussed in the following sections.

\subsection{Isolation and Identification of Citrobacter}

The procedure used was tailored towards isolation of Salmonella. Briefly, aliquot $(5 \mathrm{ml})$ of the homogenate was enriched in Selenite fluid (Tulip) (45 ml) for 24 hours, after which a loopful was streaked on Salmonella-Shigella agar (Biotech) and aerobically incubated at $37^{\circ} \mathrm{C}$ for 24 hours. Presumptive colonies (white colonies with black centres) were subcultured in Tryptose Soya agar (Oxoid) and subjected to further tests such as Gram staining, catalase test, motility test, oxidase test, indole test, urease test and triple sugar iron test. Representative isolates were forwarded to International Institute of Tropical Agriculture, Ibadan for confirmation of identity using $16 \mathrm{~S}$ rRNA gene sequencing technique. 


\subsection{Isolation and Identification of Shigella}

Presumptive colonies (white colonies without black centres) on Salmonella-shigella agar (Biotech) were subcultured in Tryptose Soya agar (Oxoid) and subjected to further tests such as Gram staining, catalase test, motility test, oxidase test, urease test and glucose fermentation test.

\subsection{Isolation and Identification of Escherichia coli}

Aliquot $(5 \mathrm{ml})$ of the homogenate was enriched in lactose bile broth $(20 \mathrm{ml})$ for 18 hours, after which a loopful was streaked on Eosin Methylene Blue (EMB) agar (Oxoid) and aerobically incubated at $37^{\circ} \mathrm{C}$ for 24 hours. Presumptive colonies (blue-black colonies with green metallic sheen and dark centres) on EMB agar were streaked on sorbitol MacConkey agar (Titan) and subcultured in Tryptose Soya agar (Oxoid) and subjected to further tests such as Gram staining, catalase test, indole test, urease test and citrate test, haemolysis test.

\subsection{Isolation and Identification of Staphylococcus}

Aliquot $(5 \mathrm{ml})$ of the homogenate was enriched in Nutrient broth (Oxoid) containing 3\% NaCl (20 ml) for 24 hours, after which a loopful was streaked on Mannitol Salt agar (Oxoid) and aerobically incubated at $37^{\circ} \mathrm{C}$ for 24 hours. Presumptive colonies (yellow colonies) were subcultured in Tryptose Soya agar (Oxoid) and subjected to further tests such as Gram staining, catalase test, coagulase test and haemolysis test.

\subsection{Isolation and Identification of Aeromonas}

Briefly, aliquot $(5 \mathrm{ml})$ of the homogenate was enriched in Nutrient broth (Oxoid) containing 3\% $\mathrm{NaCl}(20 \mathrm{ml})$ for 24 hours, after which a loopful was streaked on TCBS agar and aerobically incubated at $37^{\circ} \mathrm{C}$ for 24 hours. Presumptive colonies (yellow colonies) on Thiosulfate Citrate Bile salt Sucrose agar (TCBS) agar (Titan) were subcultured in Tryptose Soya agar (Oxoid) and subjected to further tests such as Gram staining, oxidase test, motility test, haemolysis test, lecithinase test and gelatinase test.

\subsection{Isolation and Identification of Bacillus cereus}

Aliquot $(5 \mathrm{ml})$ of the homogenate was heated in a water bath at $80^{\circ} \mathrm{C}$ for 10 mins and enriched in Brain Heart Infusion broth (Titan) $(20 \mathrm{ml})$ for 24 hours, after which a loopful was streaked on agar and aerobically incubated at $37^{\circ} \mathrm{C}$ for 24 hours. Presumptive colonies (raised grey colonies) on Brain Heart Infusion agar (Titan) were subcultured in Tryptose Soya agar and subjected to further tests such as Gram staining, spore staining, motility test, haemolysis test, lecithinase test and gelatinase test.

\subsection{Data Analysis}

Descriptive statistics such as means and frequencies were used to present some of the findings. All data on plate counts were converted to logarithmic value. Analysis of variance (ANOVA) was performed using statistical software available in Vassarstat website.

\section{Results}

The Mean bacterial loads in 300 snails analysed in this study are presented in Table 1 . The mean aerobic plate count of samples ranged from $8.43-9.61 \mathrm{Log} \mathrm{CFU} / \mathrm{g}$. Samples from Ogbete market had the highest mean total aerobic plate count $(9.32 \pm 0.308 \mathrm{Log} \mathrm{CFU} / \mathrm{g})$ while the lowest mean count was found in Igboukwu samples $(8.74 \pm$ $0.312 \mathrm{Log} \mathrm{CFU} / \mathrm{g}$ ). There were significant differences between total aerobic plate counts of all groups of samples analysed $(\mathrm{p}<0.01)$. Samples from Abakaliki market had the highest mean count of coliforms $(7.63 \pm 0.389 \mathrm{Log}$ CFU/g) while Igboukwu samples $(7.41 \pm 0.191 \mathrm{Log}$ CFU/g) had the least counts and there were no significant differences between Igboukwu and Ogbete samples. The highest mean Citrobacter counts was found in Abakaliki samples (7.24 $\pm 0.210 \mathrm{Log} \mathrm{CFU} / \mathrm{g})$ and there were no significant differences between Igboukwu and Ogbete samples $(\mathrm{p}<0.01)$. Abakaliki samples were found to contain the highest mean Shigella counts $(4.61 \pm 0.354 \mathrm{Log}$ $\mathrm{CFU} / \mathrm{g})$. There were significant differences between Shigella counts of all groups of samples analysed $(\mathrm{p}<0.01)$. Igboukwu samples contained the highest mean counts of $E$. coli $(7.14 \pm 0.170 \mathrm{Log} C \mathrm{FU} / \mathrm{g})$ and there were significant differences between all groups of samples analysed $(\mathrm{p}<$ 0.01). Staphylococcus was not detected in Igboukwu samples. The highest mean count of Aeromonas was found in Ogbete samples $(4.80 \pm 0.473 \mathrm{Log}$ CFU/g). Abakaliki samples had the highest mean counts of Bacillus cereus $(4.50 \pm 0.136 \mathrm{Log} \mathrm{CFU} / \mathrm{g})$.

Samples were found to contain different levels of bacterial loads (Table 2). All samples had total aerobic plate counts $>10^{8} \mathrm{CFU} / \mathrm{g}$. Most samples (86.7\%) had coliform counts ranging from $>10^{6}-10^{8} \mathrm{CFU} / \mathrm{g}$. While Citrobacter counts ranged from $>10^{6}-10^{8} \mathrm{CFU} / \mathrm{g}$ in all samples, Shigella counts were $<10^{4} \mathrm{CFU} / \mathrm{g}$ in $35 \%$ of the samples. E. coli counts were $>10^{6}-10^{8} \mathrm{CFU} / \mathrm{g}$ in $60 \%$ of the samples. The staphylococci counts were $>10^{4}-10^{6}$ $\mathrm{CFU} / \mathrm{g}$ in $26.7 \%$ of the samples. While Aeromonas counts were $<10^{4} \mathrm{CFU} / \mathrm{g}$ in $43.3 \%$, Bacillus cereus counts were $<10^{4} \mathrm{CFU} / \mathrm{g}$ in $60 \%$ of the samples. 
Table 1. Mean bacterial loads in snails for sale in three markets in South East, Nigeria

\begin{tabular}{|c|c|c|c|}
\hline Bacteria & Igboukwu $(\log$ CFU/g \pm SD) & Abakaliki (Log CFU/g \pm SD) & Ogbete (Log CFU/g \pm SD) \\
\hline *APC & $8.74 \pm 0.298^{\mathrm{a}}$ & $8.88 \pm 0.312^{\mathrm{b}}$ & $9.32 \pm 0.294^{\mathrm{c}}$ \\
\hline Coliforms & $7.41 \pm 0.183^{\mathrm{a}}$ & $7.64 \pm 0.371^{\mathrm{b}}$ & $7.50 \pm 0.342^{\mathrm{a}}$ \\
\hline Citrobacter & $6.38 \pm 0.086^{\mathrm{a}}$ & $7.24 \pm 0.153^{\mathrm{b}}$ & $6.37 \pm 0.210^{\mathrm{a}}$ \\
\hline Shigella & $4.44 \pm 0.221^{\mathrm{a}}$ & $4.60 \pm 0.319^{\mathrm{b}}$ & $5.08 \pm 0.549^{\mathrm{c}}$ \\
\hline E. coli & $7.15 \pm 0.163^{\mathrm{a}}$ & $6.94 \pm 0.176^{\mathrm{b}}$ & $5.65 \pm 0.228^{\mathrm{c}}$ \\
\hline Staphylococcus & - & $4.75 \pm 0.150^{\mathrm{a}}$ & $4.66 \pm 0.589^{\mathrm{a}}$ \\
\hline Aeromonas & $3.11 \pm 0.052^{\mathrm{a}}$ & $3.42 \pm 0.191^{\mathrm{b}}$ & $4.80 \pm 0.451^{\mathrm{c}}$ \\
\hline Bacillus cereus & $3.26 \pm 0.112^{\mathrm{a}}$ & $4.49 \pm 0.132^{\mathrm{b}}$ & $3.48 \pm 0.129^{\mathrm{c}}$ \\
\hline
\end{tabular}

*APC: Aerobic Plate Count, SD: Standard Deviation.

${ }^{\mathrm{a}-\mathrm{c}}$ Means in the same row with different superscripts are different $(P<0.01)$.

Table 2. Distribution of levels of bacterial loads in 300 snails for sale in three markets in South East, Nigeria

\begin{tabular}{|c|c|c|c|c|}
\hline Bacteria & $<10^{4} \mathrm{CFU} / \mathrm{g}{ }^{\mathrm{b}} \mathrm{N}(\%)$ & $>10^{4}-10^{6} \mathrm{CFU} / \mathrm{g} \mathrm{N}(\%)$ & $>10^{6}-10^{8} \mathrm{CFU} / \mathrm{g} \mathrm{N}(\%)$ & $>10^{8} \mathrm{CFU} / \mathrm{g} \mathrm{N}(\%)$ \\
\hline${ }^{\mathrm{a}} \mathrm{APC}$ & - & - & - & $300(100)$ \\
\hline Coliforms & - & - & $300(100)$ & $40(13.3)$ \\
\hline Citrobacter & - & - & - & - \\
\hline Shigella & $105(35)$ & $75(25)$ & $180(60)$ & - \\
\hline E. coli & - & $90(30)$ & - & - \\
\hline Staphylococcus & $30(10)$ & $80(26.7)$ & - & - \\
\hline Aeromonas & $130(43.3)$ & $100(33.3)$ & - & - \\
\hline Bacillus cereus & $180(60)$ & $60(20)$ & & \\
\hline
\end{tabular}

${ }^{a}$ APC: Aerobic Plate Count.

${ }^{b} \mathrm{~N}(\%)$ : Number of samples contaminated (Percentage of samples contaminated with bacterial load).

Table 3. Prevalence of bacterial pathogens in snails for sale in three markets in South East, Nigeria

\begin{tabular}{|c|c|c|c|c|}
\hline Bacteria & Igboukwu (\%) & Abakaliki (\%) & Ogbete (\%) & Total ${ }^{\mathrm{a}} \mathrm{N}(\%)$ \\
\hline Citrobacter & 100 & 100 & 100 & $300(100)$ \\
\hline Shigella & 40 & 60 & 80 & $180(60)$ \\
\hline E. coli & 90 & 80 & 100 & $270(90)$ \\
\hline Staphylococcus & - & 30 & 80 & $110(36.7)$ \\
\hline Aeromonas & 70 & 70 & 90 & $230(76.6)$ \\
\hline Bacillus cereus & 70 & 80 & 90 & $240(80)$ \\
\hline
\end{tabular}

${ }^{\mathrm{a}} \mathrm{N}(\%)$ : Number of samples contaminated (Percentage of samples contaminated with pathogen).

All 300 samples of market snails analysed in this study were found to be contaminated with pathogens irrespective of the source of the samples (Table 3). Citrobacter was detected in all samples across the three sources. Shigella was recovered from $60 \%$ of all samples analysed, with the highest prevalence in Ogbete samples (80\%). E. coli, Staphylococcus, Aeromonas, and B. cereus were recovered from $90 \%, 36.7 \%, 76.6 \%$ and $80 \%$ of all samples respectively.

\section{Discussion}

A. achatina was the focus of this study because of its conspicuous presence in the southern part of Nigeria. It is consumed by the people of both rural and urban communities (Okafor, 1989; Efuntoye et al., 2011). Land snails aestivate from December of a year to March of the next year, and re-surface during the rainy season (Fagbuaro et al., 2006) which explains why this study was conducted during the rainy season.

The findings of this study demonstrate that most snails sold in markets in Anambra, Ebonyi and Enugu states contain various levels of high loads of bacterial indicators and pathogens. The mean aerobic plate count of samples analysed in this study ranged from $8.43-9.61 \mathrm{Log} \mathrm{CFU} / \mathrm{g}$. These data appear close to the findings of other related studies: Adegoke et al. (2010) reported total aerobic bacterial count in market snails at Akwa Ibom state was 8.0 Log CFU/g. In Ghana, Nyoagbe et al. (2016) reported 
that total viable count ranged from 6.61 to $8.29 \mathrm{Log} \mathrm{CFU} / \mathrm{g}$. However, Temelli et al. (2006) found the average total aerobic bacterial count in live snails in Turkey to be 6.85 Log CFU/g. Also, mean aerobic counts varied significantly $(p<0.01)$ between the three states from which samples were collected, probably because of the difference in the nature of soil and debris present in the natural habitats of these snails across these locations.

Aerobic plate count is generally used as a means of assessing the overall microbial quality of raw ingredients (Siragusa et al., 1998). According to ICMSF (1986), the acceptable upper limit of total aerobic bacterial load for seafoods is $5.0 \mathrm{Log} \mathrm{CFU} / \mathrm{g}$ and this limit has been cited in most research articles till date. It is important to note that all snail samples analysed in this study had total aerobic plate counts $>10^{8} \mathrm{CFU} / \mathrm{g}$. This implies that $100 \%$ of market snails analysed pose microbiological risk to handlers and consumers. However, the use of the aerobic plate count as an indicator for the presence of specific pathogens is generally not satisfactory (Miskimin et al., 1976; Siragusa et al., 1998).

Coliform counts are used for assessing the amount of contamination on meat arising from gut contents and are the most frequently studied indicators (Wu et al., 2011). The acceptable upper limit of total coliform is $2.0 \mathrm{Log}$ CFU/g (ICMSF, 1986). In this study, the coliform counts were $>2.0 \mathrm{Log} \mathrm{CFU} / \mathrm{g}$ in all samples analysed. Similar coliform count in snails has been previously reported (Adegoke et al., 2010; Nyoagbe et al., 2016), even though the prevalence of levels of concentrations of coliforms in snails has not been reported in any study. It is appropriate to note that snails discharge their faeces within their habitat (Ibom et al., 2012) and may explain the high loads of coliforms observed in this study.

Citrobacter was detected in all samples across the three sources. This observation is supported by another study in India on the bacterial diversity of the gastrointestinal tract of A. fulica using culture-independent and culture-dependent methods. The study also concluded that an apparent feature of bacterial communities in snails' gastrointestinal tract was the abundance of members of the genus Citrobacter (Pawar et al., 2012). The highest mean Citrobacter count was found in Abakaliki samples (7.24 \pm $0.210 \mathrm{Log}$ CFU/g). Citrobacter is classically considered a resident commensal of the intestinal tracts of both humans and animals (Guerrant et al., 1976). It is also prevalent in soil and water through contamination from the waste materials of animals. A study concluded that healthy pet turtles are a potential carrier of $C$. freundii (Sabrina-Hossain et al., 2017). Therefore, animals are the probable source of Citrobacter around swampy environments where most snails are collected.

Mean Shigella counts exceeded $4.00 \mathrm{Log} \mathrm{CFU} / \mathrm{g}$ in all samples examined. Most studies on snails have reported the presence of Shigella without indicating its level of concentration (Adagbada et al., 2011). Several aquatic bodies have been found to contain Shigella and aquatic foods may play a role in its transmission if such foods are harvested from sewage-contaminated water (Iwamoto et al., 2010). The number of Shigella cells required to initiate infection ranges from $10^{1}-10^{4}$ cells/person (Dupont et al., 1989; Heymann, 2004). Since $60 \%$ of snails in our study exceeded $10 \mathrm{CFU} / \mathrm{g}$, it implies such percentage of snails represent health threat to handlers and consumers, especially children less than five years of age (Taneja and Mewara, 2016).

For E. coli, the highest mean counts were found in Igboukwu samples $(7.14 \pm 0.170 \mathrm{Log} \mathrm{CFU} / \mathrm{g})$, while Ogbete samples had the lowest mean counts $(5.65 \pm 0.239$ $\log C F U / g)$. Sixty percent of the snails in this study had $E$. coli counts $>6.0 \mathrm{Log} \mathrm{CFU} / \mathrm{g}$ which is within the range of counts prominent for resulting in diarrhoeal diseases $6.0-$ $9.0 \mathrm{Log}$ CFU/g (Kornacki and Marth, 1982).

The mean staphylococcal count in samples analysed in this study ranged from $4.66-4.74 \mathrm{Log} \mathrm{CFU} / \mathrm{g}$. The only study that quantified the level of Staphylococcus in snails reported a range between 2.66 and $7.68 \mathrm{Log} \mathrm{CFU} / \mathrm{g}$ (Nyoagbe et al., 2016). Diagnosis of staphylococcal food poisoning is generally confirmed by the recovery of at least 5.0 Log CFU/g from food (Halpin-Dohnalek and Marth, 1989; Hennekinne et al., 2012). It is suggested that since Staphylococcus is also present in intestinal tract, meat may contain Staphylococcus resulting from contamination with intestinal content during evisceration (Bhalla et al., 2007). It is not clear why Staphylococcus was not detected in Igboukwu samples, but may have been present at very low counts.

The mean count of Aeromonas was found to range from 3.10 - 4.80 Log CFU/g. The infectious dose of Aeromonas species in foods is not known (Isonhood and Drake, 2012). In another study, mesophilic aeromonads were isolated from $26 \%$ of vegetable samples, $70 \%$ of meat and poultry samples, and from $72 \%$ of fish and shrimps. Numbers of motile aeromonads present in these samples varied from $<$ 2.0 to $>5.0 \mathrm{Log}$ CFU/g (Neyts et al., 2000). While in our present study, $76.6 \%$ of the snail samples contained Aeromonas. This is important because snails feed on assortment of plant and animal species including algae (Okafor, 1989). Formulated feeds for snails are not available in the market. Therefore, it has become common practice for snail rearers to use vegetables, plant leaves and kitchen wastes to feed snails (Chah and Inegbedion, 2013). Aeromonas species are widely distributed in the aquatic environment (Palumbo, 1996, Neyts et al., 2000) and their prevalence in various water and food sources represents a significant public health threat (Wu et al., 2007). Edible snails sold in the markets are usually obtained from the forest and are in high demand among consumers (Nyoagbe et al., 2016). Also, they are usually purchased alive in the market by consumers and brought into homes where they are handled and prepared in the domestic kitchens.

The results of this study indicate that Bacillus counts for 
Abakaliki samples had the highest mean count of Bacillus $(4.50 \pm 0.136 \mathrm{Log} \mathrm{CFU} / \mathrm{g})$ followed by Ogbete samples $(3.48 \pm 0.135 \mathrm{Log} \mathrm{CFU} / \mathrm{g})$ and Igboukwu samples $(3.25 \pm$ $0.130 \mathrm{Log}$ CFU/g). Nyoagbe et al. (2016) reported similar levels of Bacillus in snails ranging from 1.53 to $4.90 \mathrm{Log}$ $\mathrm{CFU} / \mathrm{g}$. It is often noted that Bacillus cereus levels $>3.0$ Log CFU/g always result in illness (Harmon et al., 1992).

\section{Conclusions}

Snails displayed for sale in markets at Anambra, Ebonyi and Enugu states contain high loads of bacterial indicators and pathogens at high prevalence rate. Among the pathogens studied, highest counts were observed for Citrobacter and E. coli in samples. Edible snails may play a role in the transmission of foodborne bacterial pathogens in the food chain. Sources of edible snails should be monitored and protected from routes of bacterial contamination. There is need to collaborate with environmental professionals. Our findings highlight the need for formulation and implementation of strategies for the reduction of bacterial pathogens in edible snails along the value chain.

\section{Conflict of Interest}

The authors declare there is no conflict of interest.

\section{Author's Contribution}

Arthur C. Okafor and Frank C. Ogbo planned and conducted the research work, analyzed and interpreted the data and also drafted the manuscript.

\section{REFERENCES}

[1] Adagbada A O, Orok A B and Adesida S A 2011 The prevalence and antibiotic susceptibility pattern of entero-pathogens isolated from land snails commonly eaten in Cross River and Akwa Ibom states, South-southern Nigeria. Asian Journal of Pharmaceutical Health Sciences 1(3): 123-127.

[2] Adegoke A A, Adebayo-Tayo B C, Inyang U C, Olayinka A A and Komolafe A O 2010 Snails as meat source: Epidemiological and nutritional perspectives. Journal of Microbiology and Antimicrobials 2(1): 001-005.

[3] Amini R, Abdulamir A S, Jahanshiri F, Shan L C, Hematian A, Amini Y, Sekawi Z and Jalilian F A 2012 Isolation and identification of methicilin-resistant Staphylococcus aureus from students' coins. African Journal of Biotechnology 11: 11143-11149.

[4] Bhalla A, Aron D C and Donskey C J 2007 Staphylococcus aureus intestinal colonization is associated with increased frequency of S. aureus on skin of hospitalized patients. BMC Infectious Diseases 7: 105.

[5] Chah J M and Inegbedion G 2013 Characteristics of snail farming in Edo South Agricultural Zone of Edo State, Nigeria. Tropical Animal Health and Production 45(2): 625-631.

[6] Coker A, Isokpehi R, Thomas B, Fagbenro-Beyioku A and Omilabu S 2000 Zoonotic Infections in Nigeria: Overview from a medical perspective. Acta Tropica 76(1): 59-63.

[7] Doulgeraki A I, Paramithiotis S and Nychas G J 2011 Characterization of the Enterobacteriaceae community that developed during storage of minced beef under aerobic or modified atmosphere packaging conditions. International Journal of Food Microbiology 145: 77-83.

[8] DuPont H L 1989 Inoculum size in shigellosis and implications for expected mode of transmission. Journal of Infectious Diseases 159:1126-1128.

[9] Ebenso I, Ekwere A, Akpan B, Okon B, Inyang U and Ebenso G 2012 Occurrence of Salmonella, Vibrio and Escherichia coli in edible land snail in Niger Delta, Nigeria. Journal of Microbiology Biotechnology and Food Sciences 2(2): 610-618.

[10] Efuntoye M O, Mabekoje O O and Adekoya F A 2011 Biochemical, enterotoxigenicity and antibiogram profiles of Staphylococcus aureus isolated from intestines of snails. Journal of Microbiology and Antimicrobials 3(3): 47-50.

[11] Fagbuaro O, Oso J A, Edward J B and Ogunleye R F 2006 Nutritional status of four species of giant land snails in Nigeria. Journal of Zhejiang University Science B 7(9): 686-689.

[12] Federal Ministries of Agriculture, Environment and Health 2017 Antimicrobial Use and Resistance in Nigeria: Situation Analysis and Recommendations. Pp. 1-158

[13] Guerrant R L, Dickens M D, Wenzel R P and Kapikian A Z 1976 Toxigenic bacterial diarrhea: nursery outbreak involving multiple bacterial strains. Journal of Pediatrics 89: 885-891.

[14] Halpin-Dohnalek M I and Marth E H 1989 Staphylococcus aureus: Production of extracellular compounds and behavior in foods - A review. Journal of Food Protection $52: 267-282$

[15] Harmon S M, Goepfert J M and Bennett R W 1992 Bacillus cereus. In C. Vanderzant and D. F. Splittstoesser (eds.). Compendium of methods for the microbiological examination of foods. American Public Health Association, Washington, D.C. pp. 593-604.

[16] Havelaar A 2016 Foodborne diseases: an ongoing global challenge. Global G. A. P. Summit. September 27-28, 2016, Amsterdam.

[17] Hennekinne J A, De Buyser M L and Dragacci S 2012 Staphylococcus aureus and its food poisoning toxins: characterization and outbreak investigation. FEMS Microbiology Review 36: 815-836.

[18] Heymann D L 2004 The American Public Health Association. Control of Communicable Diseases Manual: an Official Report of the American Public Health Association. 18th edn. Washington, DC: American Public 
Health Association. 700.

[19] Hodasi J K M 1984 Some observations on the edible giant land snails of West Africa. World Animal Review 52: 24-28.

[20] Ibom L A, Okon B and Bassey B E E 2012 Egg Traits, Hatchability and Survivability of Black-Skinned, White Skinned and Crossbred Archachatina marginata Snails. International Journal of Agricultural Science and Bioresources Engineering Research 1: 10-18.

[21] Igbinosa I B, Isaac C, Adamu H O and Adeleke G 2016 Parasites of edible land snails in Edo State, Nigeria. Helminthologia 53(4): $331-335$.

[22] International Commission on Microbiological Specification for Foods 1986 Sampling plans for fish and shellfish. In ICMSF, Microorganisms in Foods. Sampling for Microbiological Analysis: Principles and Specific Applications. Vol. 2 (2nd Ed). ICMSF. University of Toronto press, Buffalo NY pp: 55.

[23] Isonhood J H and Drake M 2012 Aeromonas species in Foods. Journal of Food Protection 65: (3)575-582.

[24] Iwamoto M, Ayers T, Mahon B E and Swerdlow D L 2010 Epidemiology of seafood-associated infections in the United States. Clinical Microbiology Review 23: 399-411.

[25] Johnson J R, Kuskowski M A, Smith K, O'Bryan T T and Tatini S 2005 Antimicrobial-resistant and extraintestinal pathogenic Escherichia coli in retail foods. Journal of Infectious Diseases 191(7): 1040-1049.

[26] Kobayashi H, Pohjanvirta T and Pelkonen S 2002 Prevalence and characteristics of intimin- and Shigatoxin-producing Escherichia coli from gulls, pigeons and broilers in Finland. Journal of Veterinary Medical Science 64(11): 1071-1073.

[27] Kornacki J L and Marth E H 1982 Foodborne Illness Caused by Escherichia coli: A Review. Journal of Food Protection 45(11): 1051-1067.

[28] Logan N A, Hoffmaster A, Shadomy S V and Stauffer K 2011 Bacillus and related genera. In Manual of Clinical Microbiology editors Versalovic J, Carroll K C, Funke G, Jorgensen J H, Landry M L and Warnock DW 10th edition Vol 1 pp. 381-402 Washington D C: American Society for Microbiology.

[29] Miskimin D K, Berkowitz K A, Solberg M, Riha W E, Franke W C, Buchanan R L and O'Leary V 1976 Relationships between indicator organisms and specific pathogens in potentially hazardous foods. Journal of Food Science 41: 1001-1006.

[30] Neyts K, Huys G, Uyttendaele M, Swings J and Debevere J 2000 Incidence and Identification of Mesophilic Aeromonas Spp from Retail Foods. Letters in Applied Microbiology 31: 359-363.

[31] Nodu M B, Adesope O M and Matthews-Njoku E C 2003 Demographic characteristics related to consumption of snail meat among inhabitants of Bori, Nigeria. African Journal of Livestock Extension 2: 54-57.

[32] Nyoagbe L A, Appiah V, Nketsia-Tabiri J, Larbi D and Adjei I 2016 Evaluation of African giant snails (Achatina and Archachatina) obtained from markets (wild) and breeding farms. African Journal of Food Science 10(7): 94-104.

[33] Okafor A C, Aquaowo U A, Ojiagu K D and Agu K C 2017 Preliminary Studies on Processed Garri as a Source of Bacterial Hazards to Students. Immunology and Infectious Diseases 5(3): 25-29.

[34] Okafor F C 1989 Consumption and assimilation of food in Achatina achatina (L). Tropical Ecology 20(1): 52-57.

[35] Omenewa V C, Ansa E J, Agokei O E, Uka A and George O D 2011 Microbiological quality of raw and processed farm reared periwinkle from brackish water eastern pond, Buguma, Nigeria. African Journal of Food, Agriculture, Nutrition and Development 11(2): 4621-4630.

[36] Palumbo S A 1996 The Aeromonas hydrophila group in food. In The Genus Aeromonas ed. Austin B, Altwegg M, Gosling P J and Joseph S. Chichester, UK: Wiley and Sons. pp. 287-310.

[37] Pawar K D, Banskar S, Rane S D, Charan S S, Kulkarni G J, Sawant S S, Ghate H V, Patole M S and Shouche Y S 2012 Bacterial diversity in different regions of gastrointestinal tract of Giant African Snail (Achatina fulica). Microbiology Open 1(4): 415-426.

[38] Public Health England. (2014). Identification of Staphylococcus species. UK Standards for Microbiology Investigations, 3: 1-32.

[39] Public Health England. (2015). Identification of Aeromonas and Vibrio species. UK Standards for Microbiology Investigations, 3:1-30.

[40] Public Health England. (2015). Identification of Bacillus species. UK Standards for Microbiology Investigations, $3: 1-27$.

[41] Public Health England. (2015). Identification of E. coli O157:H7. UK Standards for Microbiology Investigations, 3:1-30.

[42] Public Health England. (2015). Identification of Shigella species. UK Standards for Microbiology Investigations, $3: 1-22$.

[43] Rauth S K and Barker G M 2002 Achatina fulica Bowdich and other Achatinidae as a pest in tropicultural agriculture. In L. R. Hamilton, ed. Mollusks as crop pest. KABI International Publishing, New Zealand. P. 474.

[44] Sabrina-Hossain S H M P, Wimalasena and Gang-Joon Heo 2017 Virulence Factors and Antimicrobial Resistance Pattern of Citrobacter freundii Isolated from Healthy Pet Turtles and their Environment. Asian Journal of Animal and Veterinary Advances 12: 10-16.

[45] Serrano S, Medina L M, Jurado M, Jodral M 2004 Microbiological quality of terrestrial gastropods prepared for human consumption. Journal of Food Protection 67: 1779-1781.

[46] Siragusa G R, Dorsa W J, Cutter C N, Bennett G L, Keen J G and Koohmaraie M 1998 The Incidence of Escherichia coli on Beef Carcasses and its Association with Aerobic Mesophilic Plate Count Categories During the Slaughter Process. Journal of Food Protection 61(10): 1269-1274.

[47] Taneja N and Mewara A 2016 Shigellosis: Epidemiology in 
India. Indian Journal of Medical Research 143(5): 565-576.

[48] Temelli S, Dokuzlu C and Sen M K C 2006 Determination of microbiological contamination sources during frozen snail meat processing stages. Food Control 17: 22-29.

[49] Toader A 2012 The influence of feed upon the Helix sp edible snail's production performance under the bioeconomic aspect. Ph.D. Thesis University of Agricultural science and veterinary medicine CLUJ-NAPOCA, Romania.

[50] Von Graevenitz A 2007 The role of Aeromonas in diarrhoea: a review. Infection 35(2): 59-64.

[51] World Health Organization 2009 Country Profile of Environmental Burden of Disease.

[52] World Health Organization 2017 Food Safety. http://www.who.int/news-room/fact-sheets/detail/food-safe ty Accessed 17th November, 2018.

[53] Wu C J, Wu J J, Yan J J, Lee H C, Lee N Y, Chang C M, Shih H I, Wu H M 2007 Clinical significance and distribution of putative virulence markers of 116 consecutive clinical Aeromonas isolates in southern Taiwan. Journal of Infection 54: 151-158.

[54] Wu J, Long S C, Das D and Dorner S M 2011 Are microbial indicators and pathogens correlated? A statistical analysis of 40 years of research. Journal of Water and Health 9(2): 265-278. 